\title{
The Acquisition of Tacit Knowledge in Culinary Industry Work-Based Learning Process and Its Development Alternative
}

\author{
Fitri Rahmawati ${ }^{\mathrm{a}, 1}$, Kokom Komariah $^{\mathrm{a}, 2}$, Rizqie Auliana ${ }^{\mathrm{a}, 3}$ \\ Department Culinary and Fashion Education \\ Faculty of Engginering,Yogyakarta State University, Yogyakarta, INDONESIA \\ 1'fitri_rahmawati@uny.ac.id, ${ }^{2}$ kokom@uny.ac.id, ${ }^{3}$ rizqie_auliana@uny.ac.id
}

\begin{abstract}
The purpose of this paper is to describe the acquisition of tacit knowledge into explicit knowledge through Work-based Learning activities in the catering industry. Research method to describe the acquisition is using survey methode. The approach use Food Processing Context with Work-based Learning (PM-WBL) model that developed by Kokom Komariah (2013). The instrument which used is consist of sheets of tasks and interviews. The research subject is 40 students of Culinary Education Engineering, FT UNY, which is implementing the catering industry practices in the industry. Data were analyzed using descriptive qualitative methode. Tacit knowledge acquisition activities into declaratif knowledge, conducted through two phases: (1) implementing work-based learning process in the catering industry, through a process of $3 \mathrm{~N}$, namely "Niteni, careful attention on activity, Nirokke imitating what has been understood and Nambahi, adding to what is obtained from the two previous processes, and (2) write the results of the learning process.
\end{abstract}

Index Terms - tacit knowledge, work-based learning.

\section{Introduction}

Vocational education has the main goal of preparing workforces. Due to this, vocational education always demand the relevance between the educational and the working world. To achieve this goal, various aspects including input and output of educational process in vocational education must be carried on continuously.

The educational system development in the form of learning as a way to develop human resources is a need that should be done as soon as possible. Although this idea is not a new one, the pioneering implementations based on a clear concept hasn't been realized as much as expected.

The success of education in vocational level will be very dependent of the educators, who serve as the main role in educational process. Educators (teachers) are vital and fundamental component in educational process, who put forth the processes of psychological and mindset maturing, and national character building to realize the true Indonesian character [1] Culinary technique education in preparing professional educator candidates in vocational field also attempts to prepare professional educator candidates for teaching in the class, starting to determine a goal, choosing materials, choosing methods and strategies and also evaluating to the learning activity.

Referring to the success of developing countries, big companies and world-class universities, the achievement is because of their ability to manage knowledge. Knowledge makes the pivots of civilization so it can develop the civilization and the prosperity. Based on this, the one that needs to be developed and managed is the intangible assets, one of them is tacit knowledge. Tacit knowledge should be developed by the students not only by learning how to cook a tasty food or making a product that can be well-received by the society, but also by being able to translate those abilities into explicit knowledge and communicate and share them to others.

The learning prosess in culinary industry, which is a work-based learning approach has a learning character in vocational education and carried out successfully by the LPTK. The industry could serve as a laboratory for culinary students, industry has tools and experience and reliable instructors. Through the interactions in the work-based learning process, the competency of the students can be developed.

The success of work-based learning still needs to be followed up. One of the reason is because the acquired knowledge and skills from the student is still in the form of tacit knowledge, which means they are still stored as a form of thought and personal. Therefore, the externalization process of the skills or tacit knowledge still need to be developed into explicit knowledge, which is a formal and systematical knowledge that can be easily shared and communicated.

Learning process using work-based learning approach in culinary industry in competence building has been able to characterize the learning in vocational education. The success of the work-based learning implementation still needs to be followed up. One of the reason is because the knowledge and skills acquired by the students from the industry are still in the form of tacit knowledge. The acquired abilities from the students are not be documented and written yet. Students' ability to write or explain still need to be developed. This is very important because someone's knowledge acquired from experience, insights, and intuition during the time in the industry could be lost and forgotten naturally by time. If the students re-telling the whole acquired experience, they might forget most of his/her own knowledge.

The purpose of this paper is to illustrate the acquisition of tacit knowledge into explicit knowledge in culinary industry on work-based learning activity through its learning process and develop the alternative so in the end the students are able to create an accountable scientific paper. 


\section{Method}

Research methods to describe the acquisition of tacit knowledge into explicit acquisition of knowledge is using survey. The approach used is a model with Context Food Processing Work-based Learning (PM-WBL) developed by Kokom Komariah [2], which features include (1) the existence of competence that can be learned, (2) the existence of learning tools, learning contracts, monitoring and feedback, (3) the interaction of learning through the process of learning experience, modeling, situated learning, and learning by doing, (4) the commitment of all the elements involved. The instrument used to see the acquisition of tacit knowledge is used sheets of tasks and interviews. The subjects were students of Culinary Education Engineering, Faculty of Engineering, Yogyakarta State University, which is implementing the catering industry practices in the industry. The subject of research are 40 students. Data were analyzed using quantitative descriptive.

\section{Results and Discussion}

The results of the research through the process of work-based learning in industry, the students can carry out various activities such as food processing preparation, perform fish, meat and vegetables cutting technique, prepare broth, seasonings and sauces, as well as students. They also can implement food processing such as Continental cuisine (Western), Oriental cuisines (Asian) and various products patiseri (snack, pastry, bakery), in accordance with the type of dish that usually served at their place of work.

Tacit knowledge acquisition activities into declaratif knowledge, in this case can only finish through two phases: (1) implementing work-based learning process in the catering industry, and (2) write the results of the learning process in the form of scientific papers or reports.

\section{a. Development Process Through Work-based Learning}

Work-based learning is a form where students can acquire tacit existing knowledge through learning in the industry. But how students can transform the tacit knowledge into explicit knowledge, it still need forms and methods, even with the tools that can "force" students to reveal their tacit knowledge. This activity refers also to the processing of information which students actively seek and process their own information with higher levels of mental processes. So that students will understand the basic concepts or make better ideas, also help the students in using their memory in order to transfer the circumstances to the new learning process. Tacit knowledge is still a hidden knowledge, whereas explicit knowledge is knowledge that able to be communicated and documented with systematically structured.

Efforts are made to transform the tacit knowledge into explicit learning refers to the process required $3 \mathrm{~N}$ expressed by Ki Hajar Dewantoro namely (1) niteni, activity marked by pay attention carefully and use the senses; (2) Nirokke which means imitating what has been understood from niteni process involving all behaviour; (3) nambahi which means adding to what is obtained from the two previous processes. $3 \mathrm{~N}$ KHD is a process of learning by seeing, feeling and doing a cycle of endless studying. Through the process of learning use the actual experience directly through observation and imitation process students are able to do something similar from the people who imitated, in this case the chef who works professionally.

Development model of tacit knowledge held in the industry implemented with site approach, which provides activities with real learning situation in the industry or employment with the procedures of planning, implementation and evaluation, but existing models are now touching the techniques of how students can absorb, adopt tacit and explicit knowledge in the industry.

Based on the research results of the development of tacit knowledge is effectively implemented because it can improve the competence of food processing which includes: carrying out the preparation of food processing, food processing implement, anticipating accidents, perform the technique on a piece of food ingredients, seasoning to prepare a variety of dishes to be processed, prepare broth in accordance with the custom in the industry, setting up all kinds of sauces, perform cleaning on the tools and cleaning materials, selecting equipment for cooking, using cooking utensils, cooking techniques with moist heat methods, techniques of cooking with dry heat method, do the packing dishes with portion according to consumers taste and give garnishes on the dish.

Raelin [3] explained thoroughly about explicit knowledge as a commonly-received sign through a form of explanation with systematic language. While implicit knowledge is a knowledge component not easily explained, because it is very basic and can only noticed through a very particular context of action. So, even if someone knows what he/she is doing, he/she might not be able to explain what is the implication of what he/she knows. Another different understanding is stated by Anderso [3] about declarative knowledge (explicit) and procedural knowledge (implicit). Declarative knowledge shows a conceptual understanding about a phenomenon, while procedural knowledge shows the ability to do something physically or mentally.

Combining the forms of both explicit knowledge and tacit knowledge, Raelin [3] illustrated it in WBL (workbased learning) done by an individual or a group in the following table:

Table 1. Explicit and tacit knowledge model conception in individual level

\begin{tabular}{ccc}
\hline \multirow{2}{*}{ Model of Learning } & \multicolumn{2}{c}{ Form of knowledge } \\
\cline { 2 - 3 } & Explicit & Tacit \\
\hline Theory & Conceptualization & Experimentation \\
Practice & Reflection & Experience \\
\hline & & (Source: Raelin, 2008)
\end{tabular}

Table 1 above explained that conceptualization as a theoretical framework contributes to the strength of new problem analysis in different context. Experimentation is the chance to transform conceptual knowledge to do-able contextual knowledge. Experience; a learning happens through experience, so students could reflect their experience. A learning through experience strengthen the tacit knowledge which gained from experiments. Reflection is a meaning reconstruction. The ability to find and clarify what has been planned, observed, and achieved in the practice. 
Some concepts that relevant and can be made into a guide steps to insert WBL elements in learning at work; which is the learning in a workplace, learning through work; which is a learning through or with working, learning for work; by doing something new better, and learning from work; by using the experience gained from work.

Tacit knowledge is a knowledge that generally not yet documented because this knowledge commonly still hidden in someone's ability. Generally it still relates to practices. It is an unwritten knowledge, not explained also. This knowledge can be based on experience, insight, and intuition of an individual. Tacit knowledge is a knowledge that we store in our mind and the form is invisible. If compared quantitatively, there are much more tacit knowledge than explicit knowledge.

Explicit knowledge is a widely-received signs through a form of explanation with systematic language. Implicit knowledge is a knowledge component that not easily explained because it is very basic and can only be seen in an action with a very particular context. So even if someone knows what he/she is doing, he/she might not be able to explain what is implied by what they know. Another different take is stated by Anderson [3] about declarative knowledge (explicit) and procedural knowledge (implicit). Declarative knowledge shows a conceptual understanding about a phenomenon, while procedural knowledge shows an ability to do something physically or mentally.

Knowledge and abilities in food processing field generally are still in the form of tacit knowledge. Meanwhile, a student, as an educator candidate needs explicit knowledge, a formal knowledge that can be transferred or shared to other people. WBL method is expected to create several explicit knowledge concepts on core food processing materials through a determined learning steps.

Other weaknesses that appear in the implementation of the industry practice of tacit knowledge development model is appear from the students where each student has different abilities, lecturers are lacking in monitoring the implementation of industry practices, and industry mentors are more profit-oriented and production targets rather than on learning.

Scientific approach, as suggested by the 2013 curriculum, could be used as development process of tacit knowledge into explicit knowledge in work-based learning process. The approach in question includes these activities:

1) Observing, the participants do an orientation to all of the activities in the field, observing new things, new objects, how workers work, new tools, production processes and other things of interest.

2) Asking, the participants make various questions around the things of interest. $5 \mathrm{~W}+1 \mathrm{H}$ concept could be used to develop the questions, which are; what, why, when, where, who, and how.

3) Exploring, participants do exploration and observation activities to the process they will experience in workbased learning process. Even in this stage, students could carry out learning process marked by the indicators made by Kokom Komariah (2013): adjusting self with the work environment, do the relevant activities, try doing new things, repeating the same activity, working individually, working in a group, serious self involvement, interacting with instructors, trying a special work tool, interacting with materials, working with the procedures, and working as exampled.

4) Associating, the participants write down various things that found in the field, such as material types, seasonings, recipes, work procedures, how to decorate, how to present food, working atmosphere and other things of interest.

5) Communicating, the instructors as a facilitator need to give a room to the participants so they could communicate and reflect everything they know. Based on the $5 \mathrm{M}$ processes above, it's clear that tacit knowledge could be developed into explicit knowledge. More on the older learner level, who are the college students.

The processes could be developed further with modifying or creating, so the participants are not only able to gain knowledge from work-based learning in the industry or the field, the gained knowledge that has become explicit knowledge could be modified into something special, colored by the previously gained knowledge.

\section{b. Development Through Writing Reports}

In accordance with the need of students in college, they have to be able to write a scientific report. After WBL process, students are obliged to train for transforming these various tacit knowledge into explicit or declarative knowledge through a form of receivable explanation with systematical language, and able to explain what is implied from whatever they know.

Tacit knowledge development covered in scientific paper, is a way to describe an object or telling an event as an underlying proof of a experience including with comments or theory analysis. The development through scientific paper writing is guided by lecturer with inductive approach based on empirical experience in the field. Students are expected to be able to elaborate the facts, concepts, and procedures in the field.

How to write a scientific paper, based on what is stated by Suminto A. Sayuti [4] is by: topic selection has to suit to what is learned; (2) uniting ideas must be relevant with the topic, being coherent, which is able to connect supporting ideas, a clear relation between words, subject and predicate, and predicate with object; (3) completing topic ideas with explanations, examples, proofs, description, and even arguments can be developed; (4) concluding the created topic, and (5) editing the script, cover, and image designs.

Based on these, through a scientific paper writing, students as teacher, educator, and scientist candidates are expected to be able to train for transforming various tacit knowledge into explicit or declarative knowledge through a receivable form of explanation with systematic language, able to explain what is implied from what they know.

In this scientific paper writing process, it needs to be stressed of scientific behaviour, which is a must-have behaviour for scientists or academics when facing scientific problems. These scientific behaviours are:

1) Curiosity, this is seen from the habit of questioning 
everything on the learned field, such as what, why, how, etc.

2) Critical, this is seen from the habit of gathering as much information as possible on the related field to compare the pluses and minuses, compatibilities, right or wrong, etc.

3) Open minded, seen from the habit of willing to listen to other opinions, arguments, critics, and other's explanations although they might not be accepted due to the different views.

4) Objective, seen from the habit of stating something real without any personal feelings.

5) Respect for others' work, seen on the habit of citing the source of references, statements, or opinions clearly when they are originated from other people.

6) Dare to defend the truth, seen on the persistence of defending the facts and findings in the field or developments although they contradict or unsuitable with existing theory or postulates.

7) Futuristic, reaching for the future. This behaviour is proven by the willingness to always prove the proposed hypothesis for the development of the related knowledge.

\section{Conclusion}

Based on the two stages, the tacit knowledge process owned by the practitioners in the industry could be developed into explicit knowledge through two stages, which are by learning process and scientific writing. The first stage of learning process is carried out by $3 \mathrm{~N}$ : niteni (observing), niroke (imitating), and nambahi (adding), or $5 \mathrm{M}$ processes: observing, asking, exploring, associating, and communicating. The second stage is by writing a scientific paper which is determining a topic suited to the learned subject matter, uniting ideas so they keep tied to the topic, completing the topic ideas with explanations, examples, proofs, descriptions and even arguments, concluding the topic, and editing the script, cover, and design an image.

\section{References}

[1] Baedhowi. "Tantangan Pendidikan Masa Depan dan Kiat Menjadi Guru Profesional”. Jakarta. Depdiknas 2009

[2] Kokom Komariah "Pengembangan Model Pembelajaran Pengolahan Makanan dalam Konteks Work-Based Learning di Industri Boga bagi Mahasiswa Program Diploma III". Disertasi Doktor, tidak diterbitkan, Universitas Negeri Yogyakarta, Yogyakarta. 2013.

[3] Raelin J,A.. "Work based learning”. San Fransisco: Jossey Bass. 2008

[4] Sayuti. "Bahan presentasi Workshop Rekonstruksi MKU Bahasa Indonesia". Yogyakarta: Pusat Pengembangan dan Pelayanan Bahasa. 2006. 